\title{
Production of PHAs from Waste Frying Oil by Pseudomonas fluorescens S48 Using Different Bioreactor Feeding Strategies
}

\author{
Rawia F. Gamal, Hemmat M. Abd El-Hady, Enas A. Hassan, \\ Taha A. Khodair, T. S. El-Tayeb and Khadiga A. Aboutaleb \\ Department of Microbiology, Faculty of Agriculture, Ain \\ Shams University, Shoubra El-Kheima, Cairo, Egypt.
}

\begin{abstract}
R IODEGRADABLE polyesters, polyhydroxyalkanoate (PHAs) are promising candidates for the development of environmentfriendly and totally biodegradable plastics. The production of PHAs by Pseudomonas fluorescens S48 was examined using bioreactor as one-stage batch, two-stage batch, and fed-batch (pulsed, continuous and high cell density) cultures. Corn oil, soybean oil (extracted from their meal) and two types of waste frying oils (WFO) were used in productive medium as a carbon source. The highest values of polymer content in the one-stage bioreactor fermentation (52\% and $76.53 \%$ ) were obtained after $60 \mathrm{~h}$ on media supplemented with extracted corn oil and soybean oil, respectively. Whereas, the highest figure obtained on WFO type 2 was $30 \%$ under the same circumstances. Using bioreactor as a two-stage batch culture increased the polymer content with soybean, corn oil and WFO type 2 by $2.2 \%, 32.11 \%$ and $58 \%$, respectively as compared with that obtained in one-stage batch culture. High-cell-density $\left(0.64 \mathrm{gl}^{-1}\right)$ at continuous feeding rate $0.55 \mathrm{mll}^{-1} \mathrm{~h}^{-1}$ of WFO type 2 recorded the highest polymer content, yield and conversion coefficient after $48 \mathrm{~h}$. Moreover, this application increased the polymer content by $65.7 \%$ than that obtained in onestage batch culture as well as reduced the fermentation period $12 \mathrm{hr}$.
\end{abstract}

Keywords: Pseudomonas fluorescens S48, PHAs, Batch, Two-stage batch, High-cell-density, Bioreactor.

Growth in the human population has led to the accumulation of huge amounts of non-degradable waste materials across our planet. The increasing effect of nondegradable plastic wastes is a growing concern. Biodegradable polymers have extremely attracted much public and industrial interest as a consequence of extensive discussions looking for better waste-management strategies (Steinbüchel, 1995). Their physical properties make them very convenient in utilization. The use of biodegradable polymers allows composting as an additional way for waste disposal. Furthermore, the use of these polymers opens several new applications in medicine, agriculture and industry. Research into the production of PHAs as petrochemical alternatives for the future has been

Contact authors e-mails: rawiagamal123@ yahoo.com (Rawia F. Gamal), hemmatabdelhady @ yahoo. com. (Hemmat M. Abd El-Hady), enasath @hotmial. com (Enas A. Hassan), tarekeltayeb @ yahoo. com (Tarek S. El-Tayeb) and Khadigaaboutaleb @ y mail. com (Khadiga A. Aboutaleb) 
explored using bacterial and plant systems. Accumulation of intracellular storage polymers has been considered a strategy used by bacteria to increase survival in a changing environment. The ability to store PHB is an example of this characteristic and usually reflects a transient abundance of carbon sources with respect to other nutrients such as nitrogen and phosphorus (Jacquel et al., 2008). PHA has been industrially produced by pure cultures including Alcaligenes latus, Azotobacter vinelandii, Pseudomonas oleovorans, recombinant Alcaligenes eutrophus and recombinant Escherichia coli (Lee \& Choi, 1998; Grothe et al., 1999 and Grothe \& Chisti, 2000). From the literature, one of the limiting factors in the commercial success of PHB and other PHAs production schemes is the cost of the substrate used for PHA formation. Vegetable oils have been found to be possible substrates in the production of PHAs (Alias \&Tan, 2005). Waste frying oils which are even cheaper than purified oils can be used too (Fernández et al., 2005). Since deep frying is popular, there is a potential to turn this waste resource into a useful biomaterial. Akiyama et al. (2003) reported a yield of $0.8 \mathrm{~g}$ PHA per $\mathrm{g}$ plant oil and $0.3 \mathrm{~g}$ PHA per $1 \mathrm{~g}$ glucose. In the past few years, a number of mechanistic models for the production of PHAs have been constructed. Models for fermentation with simple batch culture, two-stage fedbatch process and single fed-batch fermentations are frequently described (Patwardhan \& Srivastava, 2004; Yan et al., 2005 and Lee \& Gilmore, 2006). In a laboratory scale bioreactor, With canola oil as carbon source, the polymer content of the cell dry matter of Wautersia eutropha was $90 \%$ by fed-batch process (Lopez-Cuellar et al., 2011). Verlinden et al. (2011) stated that, when Cupriavidus necator grown on oils the biopolymer produced was found to be chemically pure PHB and the molecular weights of polymers from waste frying were similar to those from other oils and glucose.

This study was conducted to examine the feasibility of using extracted oil from soybean meal, corn meal as well as two types of waste frying oils (WFO) to produce PHAs using bioreactor as a batch culture, two-stage, fed-batch with pulsed and continuous feeding in addition to high cell density fed-batch technique. Fermentations were carried out to maximize the production of the polymer (PHAs) by choosing the accurate and reliable fermentation technique.

\section{Materials and Methods}

\section{Bacteria used}

Pseudomonas fluorescens S48 was used throughout this investigation as an intracellular bioplastic polymer producer which was previously isolated, identified and confirmed as PHAs accumulation by Gamal et al. (2011). The bacterial culture was maintained by transferring at regular intervals on nutrient agar slants. Slants were kept at $4^{\circ} \mathrm{C}$.

\section{Media used}

Nutrient agar medium (Jacobs \& Gerstein, 1960) was used for bacterial culture preservation, while the medium without agar was used for inoculum preparation. Modified Kim medium (Gamal et al., 2011) which contained $\left(\mathrm{gl}^{-1}\right)$

Egypt. J. Microbiol. 47 (2012) 
glucose 10, $\left(\mathrm{NH}_{4}\right)_{2} \mathrm{SO}_{4}$ 1.0, $\mathrm{KH}_{2} \mathrm{PO}_{4}$ 1.5, $\mathrm{Na}_{2} \mathrm{HPO}_{4} .12 \mathrm{H}_{2} \mathrm{O} 9.0, \mathrm{MgSO}_{4} .7 \mathrm{H}_{2} \mathrm{O} \quad 0.2$ $\mathrm{PH} 6.8$ and $1 \mathrm{ml}$ of trace elements solution $\left(\mathrm{FeSO}_{4} .7 \mathrm{H}_{2} \mathrm{O} 10, \mathrm{ZnSO}_{4} .7 \mathrm{H}_{2} \mathrm{O} 2.25\right.$, $\mathrm{CuSO}_{4} .5 \mathrm{H}_{2} \mathrm{O} \quad 1.0, \mathrm{MnSO}_{4} \cdot 4 \mathrm{H}_{2} \mathrm{O} \quad 0.5, \mathrm{CaCl}_{2} .2 \mathrm{H}_{2} \mathrm{O} \quad 2.0, \mathrm{Na}_{2} \mathrm{~B}_{4} \mathrm{O}_{7} .10 \mathrm{H}_{2} \mathrm{O} \quad 0.23$, $\left(\mathrm{NH}_{4}\right)_{6} \mathrm{Mo}_{7} \mathrm{O}_{24} 0.1$ and $\left.35 \% \mathrm{HCl} 10 \mathrm{ml}\right)$. The productive medium contained modified Kim medium with the substitution of glucose with $2 \%$ corn oil, $1 \%$ soybean oil or $1 \%$ waste vegetable oil (either deep-fries chips or eggplant which represented type 1 or type 2 ,respectively ).

\section{Preparation of bacterial inoculum}

A conical flask $(250 \mathrm{ml})$ containing $50 \mathrm{ml}$ of nutrient broth medium was inoculated with a loop of Ps. fluorescens S48 and incubated at $28-30^{\circ} \mathrm{C}$ with shaking $(300 \mathrm{rpm})$ for $24 \mathrm{~h}$ prior to inoculation .

\section{Bioreactor experiments}

A 2L dished bottom bioreactor Z6110/Coob (Cole-Parmer Instrument) was used, which consisted of 3 liter vessel equipped with lipseal stirrer assembly, automatic $\mathrm{pH}$ controller, automatic dissolved $\mathrm{O}_{2}$ controller, $\mathrm{CO}_{2}$ controller, automatic temperature controller, foam controller and multi-channel peristaltic pump (for feeding). The PHAs producing bacteria were grown in the bioreactor as batch, two-stage batch and fed-batch (pulsed, continuous and high cell density) cultivation. During all fermentations, temperature, dissolved $\mathrm{O}_{2}$ and agitation speed were kept at $30^{\circ} \mathrm{C}$, $20 \%$ of saturation and $500 \mathrm{rpm}$, respectively. Initial $\mathrm{pH}$ was adjusted to $7 \pm 0.1$ which was not controlled during the fermentation period. Samples $(10 \mathrm{ml})$ were aseptically withdrawn from the fermentation vessel periodically. The samples were centrifuged at $15000 \mathrm{x} \mathrm{g}$ for $4 \mathrm{~min}$ at $4^{\circ} \mathrm{C}$. The sediment (biomass) was washed twice with distilled water, and then dried at $70^{\circ} \mathrm{C}$ to constant weight. Polymer in bacterial cells was determined using the chloroform-sodium hypochlorite method (Hahn et al., 1994). Residual carbon was determined in supernatant according to Walinga et al. (1992). PHAs and copolymer parameters were calculated. The parameters of polymer production; yield $(\%)$, conversion coefficient $(\%)$ and carbon utilization efficiency were calculated according to Ramadan et al. (1985). Polymer content (\%) and productivity were calculated according to Lee \& Choi (1998) and Lee (1996), respectively.

\section{Bioreactor as a batch culture (one-stage)}

In this experiment, the fermentation vessel containing $1950 \mathrm{ml}$ productive medium was autoclaved at $121^{\circ} \mathrm{C}$ for $20 \mathrm{~min}$. The bioreactor was inoculated with $1 \%$ standard inoculum $\left(5 \times 10^{8} \mathrm{cfu} / \mathrm{ml}\right)$ of Ps. fluorescens $\mathrm{S} 48$. The final working volume was 2 liter.

\section{Bioreactor as two-stage culture}

The production of PHAs was carried out by two-stage cultivation. In the first stage, 1 liter of nutrient broth inoculum culture of Ps. fluorescens S48 was centrifuged at $15000 \times \mathrm{g}$ for $4 \mathrm{~min}$ at $4{ }^{\circ} \mathrm{C}$ and the bacterial cells were collected and suspended in additional sterile productive medium to inoculate the fermentation vessel to give a final working volume of 1 liter. 
Bioreactor as fed-batch culture

Two fermentations were applied to produce PHAs by Ps. fluorescens S48 using pulsed and continuous feeding of oil. In the pulsed oil feeding, the amount of WFO type $2\left(10 \mathrm{ml}^{-1}\right)$ was added to fermentation vessel. Two, three and four additions of this amount of WFO were added during the first 12, 36 and $48 \mathrm{~h}$ of cultivation period (fed-batch by pulsed feeding). In the second fermentation, the WFO type 2 was fed continuously during the first 12,18 and $24 \mathrm{~h}$ of cultivation period at rates of $0.83,0.55$ and $0.42 \mathrm{ml}^{-1} \mathrm{~h}^{-1}$, respectively (fed-batch by continuous feeding). The final working volume in bioreactors was 1 liter at the end of feeding period.

\section{High-cell-density fed-batch culture}

Three experiments of continuous fed-batch cultures were constructed to study the effect of washed high-cell-densities of Ps. fluorescens S48 (0.36, 0.64 and $0.74 \mathrm{gl}^{-1}$ ) on PHAs production. WFO type 2 was fed continuously at $0.55 \mathrm{mll}^{-1} \mathrm{~h}^{-1}$ during the first $18 \mathrm{~h}$ of cultivation.

\section{Statistical analysis}

The collected data were statistically analysed using IBM $^{\circledR}$ SPSS $^{\circledR}$ Statistics software (2011).

\section{Results and Discussion}

The research aimed to develop an advanced process for production of biodegradable PHAs by using renewable resource as the feedstock. It is known that the cost of raw materials for the production of bioplastic is one of the limiting economic factors in the scaling up of such process. Therefore, this study was constructed to examine the feasibility of using oil extracted from soybean meal, corn meal as well as two types of WFO to produce PHAs using bioreactor as one-stage batch, two-stage and fed-batch cultures techniques.

\section{Batch culture (one-stage)}

In one-stage batch culture, where any of the oils were used as the sole carbon source, increasing the fermentation period led to a gradual increase in cell dry weight of Ps. fluorescens S48 (Fig. 1). On the other hand, PHAs production was started during the exponential phase of growth (after $12 \mathrm{~h}$ ) then sharply increased to achieve the highest figures of yield and content $(26.09,52 \%$ and 36.71 , $76.53 \%$ ) during stationary phase after $60 \mathrm{~h}$ fermentation period on media supplemented with extracted corn oil and extracted soybean oil, respectively. The corresponding figures of productivity were 0.03 and $0.044 \mathrm{gl}^{-1} \mathrm{~h}^{-1}$, respectively.

Using any of the two types of WFO as the sole carbon source for PHAs production by Ps. fluorescens S48, recorded the lowest values of cell dry weight, PHAs concentration, content, yield and productivity than that obtained on media containing meal oils. It is also interesting to notice that PHAs production was delayed to start after $30 \mathrm{hr}$ of fermentation period in medium contained WFO

Egypt. J. Microbiol. 47 (2012) 
type 1. WFO type 2 was chosen for further studies since it enhanced the production of the polymer to reach the maximum (30\% content and $0.69 \mathrm{gl}^{-1}$ ) after $60 \mathrm{~h}$ comparing with those obtained using WFO type 1 . Regarding to polymer parameters using WFO type 2, the highest values of PHAs yield, and productivity were $9.14 \%$ and $0.012 \mathrm{gl}^{-1} \mathrm{~h}^{-1}$, respectively. In the same regard Fern'andez et al. (2005) reported that PHA accumulation ranged between $66.1 \%$, $29.4 \%$ and $16.8 \%$ when waste-free fatty acids (from soybean oil) (WFFA), waste frying oil (WFO) and glucose were used as carbon substrate by Pseudomonas aeruginosa $42 \mathrm{~A} 2$, respectively.
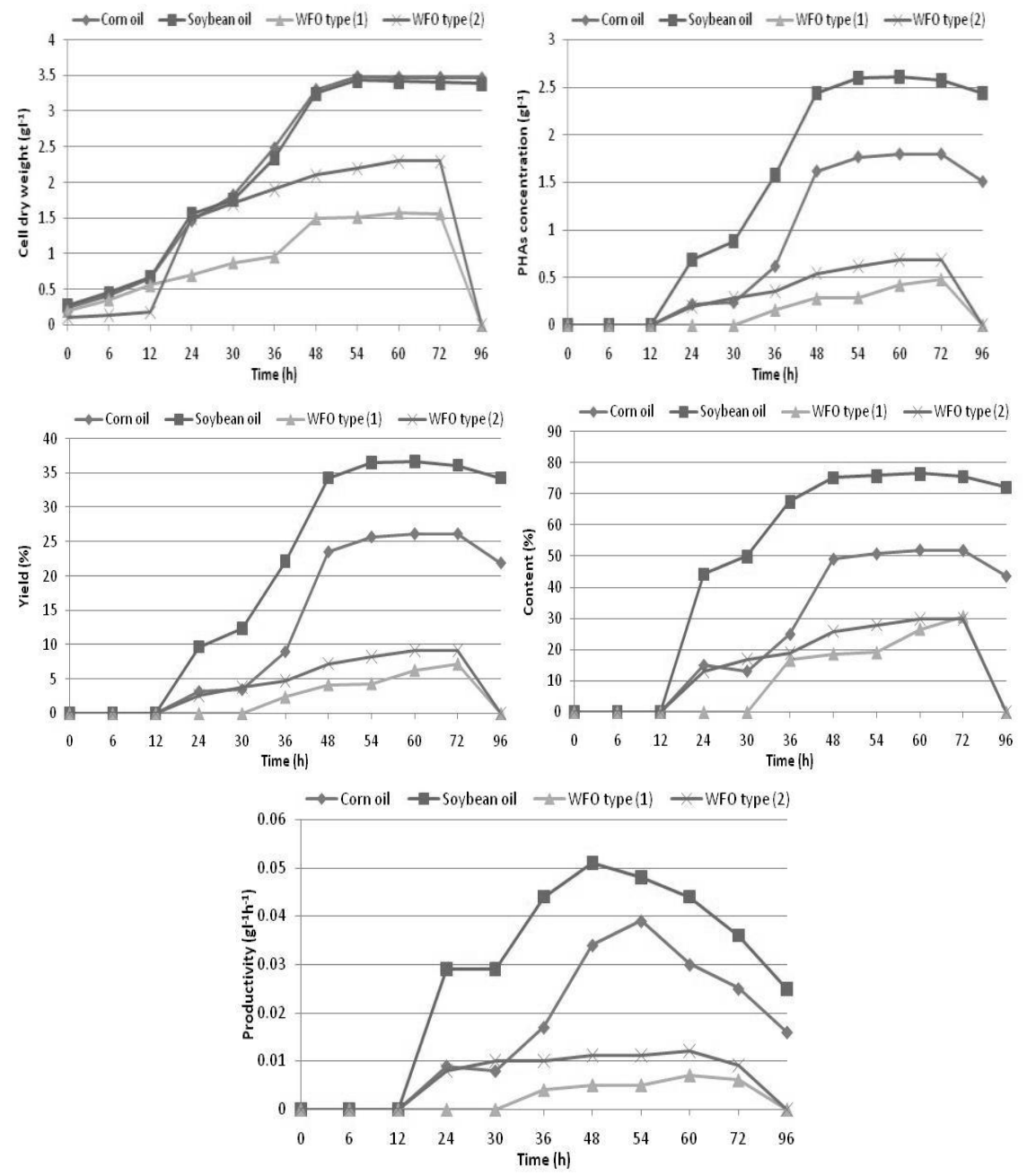

Fig. 1. Growth of Ps. fluorescens S48 and PHAs production in productive medium containing any of $2 \%$ corn oil, $1 \%$ soybean oil or $1 \%$ waste frying oil (WFO) (type 1 and 2) as carbon sources during $96 \mathrm{hr}$ at $30^{\circ} \mathrm{C}$ using bioreactor as a batch culture. 
Two-stage batch culture

In the two stage batch culture, cell dry weight of Ps. fluorescens S48 and PHAs concentration were increased gradually during the second stage of cultivation (production stage) to reach the maximum values after $60 \mathrm{hr}$ in productive medium containing either of $2 \%$ corn oil or $1 \%$ soybean oil (4.35, $2.96 \mathrm{gl}^{-1}$ and 4.53, $3.44 \mathrm{gl}^{-1}$ ), respectively (Fig. 2). The highest values of PHAs content was attained after $48 \mathrm{~h}(68.7 \%)$ using corn oil and $78.2 \%$ using soybean oil, respectively. The corresponding figures of yield, productivity and conversion coefficient were $39.9 \%, 0.057 \mathrm{gl}^{-1} \mathrm{~h}^{-1}, 74.9 \%$ and $45.7 \%, 0.066 \mathrm{gl}^{-1} \mathrm{~h}^{-1} \& 67 \%$ for corn oil and soybean oil, respectively.
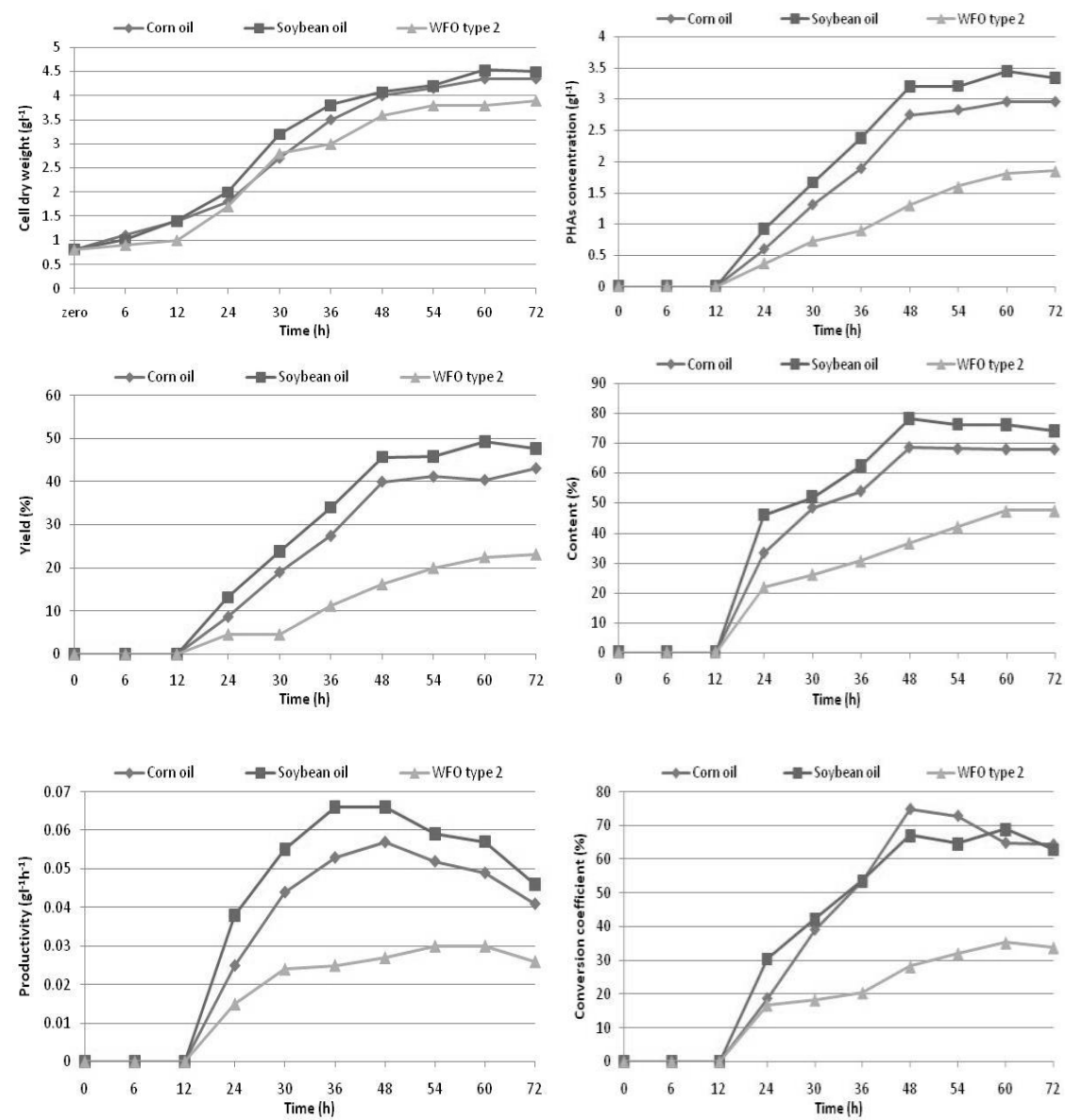

Fig. 2. Growth of Ps. fluorescens $\mathbf{S} 48$ and PHAs production in productive medium containing any of $2 \%$ corn oil, $1 \%$ soybean oil or WFO type 2 as carbon sources during $72 \mathrm{~h}$ at $30^{\circ} \mathrm{C}$ using bioreactor as a two-stage culture.

With respect to potential of Ps. fluorescens S48 to produce PHAs on WFO type 2 as the sole carbon source, results indicated that the yield of cell dry weight was $3.8 \mathrm{gl}^{-1}$ after $54 \mathrm{~h}$ of the second cultivation stage, whereas the maximum PHAs Egypt. J. Microbiol. 47 (2012) 
concentration, content and yield were obtained at the end of fermentation period (72h) $\left(1.85 \mathrm{gl}^{-1}, 47.43 \%\right.$ and 23.13 , respectively). The corresponding figures of productivity and conversion coefficient were $0.026 \mathrm{gl}^{-1} \mathrm{~h}^{-1}$ and $33.82 \%$, respectively. From the above mentioned results, it could be concluded that using bioreactor as a two stage batch culture increased the polymer content on soybean oil, corn oil and WFO type 2 when used singly as sole carbon sources by $2.2 \%, 32.11 \%$ and $58 \%$, respectively as compared with that obtained by one-stage batch culture.

\section{Fed-batch culture}

Pulsed and continuous oil feeding

Pulsed addition of WFO type 2 was carried out every 12 or 24 h during the first $48 \mathrm{~h}$ of fermentation period. Two, four and three pulsed addition was applied during the first 12,36 and $48 \mathrm{~h}$ of fermentation period with specific addition rate of $0.058 \mathrm{mll}^{-1} \mathrm{~h}^{-1}, 0.039 \mathrm{mll}^{-1} \mathrm{~h}^{-1}$ and $0.023 \mathrm{mll}^{-1} \mathrm{~h}^{-1}$, respectively (Table 1). Generally, it could be noticed that after $60 \mathrm{~h}$ of cultivation, the highest figure of cell dry weight of Ps. fluorescens S48, PHAs concentration, yield, productivity and conversion coefficient were recorded at the specific addition rate of $0.058 \mathrm{mll}^{-1} \mathrm{~h}^{-1}$ $\left(1.7 \mathrm{gl}^{-1}, 0.35 \mathrm{gl}^{-1}, 4.29 \%, 0.006 \mathrm{gl}^{-1} \mathrm{~h}^{-1}\right.$ and $6.13 \%$, respectively). Whereas, the highest values of polymer content and utilized carbon were $26.82 \%$ and $6.82 \%$, respectively at the specific addition rate of $0.023 \mathrm{mll}^{-1} \mathrm{~h}^{-1}$. Data also revealed that the polymer productivity were constant at the specific addition rates of 0.039 and $0.023 \mathrm{mll}^{-1} \mathrm{~h}^{-1}$ after $48 \mathrm{~h}$ till the end of cultivation.

The effect of different continuous feeding of WFO type 2 on the production of PHAs during $96 \mathrm{~h}$ fermentation period revealed that cell dry weight and PHAs concentration increased gradually during fermentation period to reach the maximum after $72 \mathrm{hr}$. Whereas, the maximum values of carbon utilized and carbon utilization efficiency were recorded at the end of fermentation period (96 h) (Table 2). After $72 \mathrm{~h}$, a slight increase in polymer concentration was noticed with decreasing the continuous oil feeding from 0.83 to $0.55 \mathrm{mll}^{-1} \mathrm{~h}^{-1}$ with a slight increase in polymer content from $41.2 \%$ to $41.88 \%$. On the other hand, increasing the cell dry weight and polymer concentration at the feeding rate of $0.42 \mathrm{mll}^{-1} \mathrm{~h}^{-1}$, led to decrease the polymer content to $36.14 \%$ with increasing of the yield and conversion coefficient to $7.5 \%$ and $12.3 \%$, respectively. The highest polymer productivity $\left(0.014 \mathrm{gl}^{-1} \mathrm{~h}^{-1}\right)$ was recorded after $24 \mathrm{~h}$ at the feeding rate of $0.55 \mathrm{mll}^{-1} \mathrm{~h}^{-1}$.

The previous results indicated that the pulsed and continuous feeding of waste frying oil type 2 led to decrease the polymer content about $43.4 \%$ and $11.7 \%$ than that obtained by two-stage batch bioreactor technique. Whereas, continuous oil feeding at $0.55 \mathrm{mll}^{-1} \mathrm{~h}^{-1}$ increased the polymer content about $39.6 \%$ than that obtained by the one-stage batch technique. So, it could be stated that the fed-batch culture with continuous feeding have positive impact on the PHAs production by $P$ s. fluorescens $\mathrm{S} 48$ on productive medium containing WFO type 2 as carbon source. These results were in agreement with those obtained by Shahhosseini (2004), Valappil et al. (2007) and Sun et al. (2007), they used fedbatch culture technique for PHAs production by Ralstonia eutropha, B. cereus and Ps. putida KT2400, respectively. 
High-cell-density fed-batch culture

This experiment was performed to study the behavior of Ps. fluorescens S48 to assimilate WFO type 2 for the production of PHAs using different concentrations of high-cell-density in bioreactor as a fed-batch culture at continuous WFO feeding of $0.55 \mathrm{mll}^{-1} \mathrm{~h}^{-1}$. Data recorded in Table 3 show that the cell dry weight of $P S$. fluorescence S48 was increased gradually with increasing the fermentation period to reach the maximum values $\left(1.75\right.$ and $\left.3.92 \mathrm{gl}^{-1}\right)$ after 48 and $54 \mathrm{~h}$ at the fed batch cultures started with cell densities of $0.36 \mathrm{gl}^{-1}$ and $0.64 \mathrm{gl}^{-1}$, respectively. On the contrary, the cell dry weight decreased sharply during fermentation period at the highest cell density treatment. The highest figures of PHAs concentration, content, yield and conversion coefficient were attained after $48 \mathrm{~h}$ at $0.64 \mathrm{gl}^{-1}$ cell density $\left(1.72 \mathrm{gl}^{-1}, 49.71 \%, 21.5 \%\right.$ and $29 \%$, respectively). This treatment enhanced the productivity to three fold and minimized the fermentation period by $12 \mathrm{~h}$ comparing with the lowest inoculum density treatment $\left(0.36 \mathrm{gl}^{-1}\right)$ at $60 \mathrm{~h}$. The highest utilized carbon and carbon utilization efficiency were recorded after $72 \mathrm{~h}$ at the cell density of $0.64 \mathrm{gl}^{-1}\left(6.95 \mathrm{gl}^{-1}\right.$ and $86.88 \%$, respectively). Also, it could be stated that starting the fed-batch culture with feeding of WFO type 2 at $0.55 \mathrm{mll}^{-1} \mathrm{~h}^{-1}$ with $0.74 \mathrm{gl}^{-1}$ cell density had negative impact on the PHAs production by $P$ s. fluorescens $\mathrm{S} 48$ on productive medium.

The potentiality of Ps. fluorescens to accumulate PHAs using oil in productive media were varied according to the feeding strategies, type of oil and fermentation technique which can be recorded in Table 4 and summarized in the following items:

- Productive medium containing soybean $1 \%$ using two-stage bioreactor reduced the time of maximum PHAs figure by $12 \mathrm{~h}$ comparing with batch bioreactor and gave approximately similar content of polymer $(78.2 \%)$. Whereas, PHAs content was increased to about 1.3 fold on productive medium containing $2 \%$ corn oil being $68.7 \%$ under the previous circumstances.

- High- cell- density $\left(0.64 \mathrm{gl}^{-1}\right)$ at continuous WFO type 2 feeding rate of $0.55 \mathrm{mll}^{-1} \mathrm{~h}^{-1}$ increased the polymer content by $65.7 \%$ and reduced the fermentation period by $12 \mathrm{~h}$ comparing with one-stage batch culture.

From the holistic economic vision, using waste frying oil was the first choice, as the amount of disposed frying oils was several millions of tons annually in Egypt, since $40 \%$ of the expenditure of PHAs production is the cost of the carbon source. Here in the amount of soybean oil and corn oil which were extracted from their meals were $3.4 \%$ and $2.2 \%$, respectively. The latter oils can be successfully used in the commercial scale if there are reliable and cheap methods for their extraction in order to minimize the expenditures of bioplastic production.

Acknowledgment: The authors are pleased to acknowledge Science and Technology Development Fund (STDF) for financial support.

Egypt. J. Microbiol. 47 (2012) 
PRODUCTION OF PHAS FROM WASTE FRYING OIL ...

TABLE 1. Growth of Ps. fluorescens S48 and PHAs production on productive medium using bioreactor as fed-batch culture by pulsed WFO type 2 feeding at specific addition rates of $0.058,0.039$ and $0.023 \mathrm{mll}^{-1} \mathrm{~h}^{-1}$.

\begin{tabular}{|c|c|c|c|c|c|c|c|c|c|c|c|}
\hline \multirow[b]{2}{*}{ 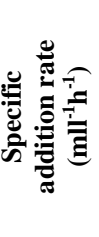 } & \multirow[b]{2}{*}{ 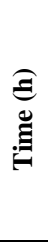 } & \multirow[b]{2}{*}{ 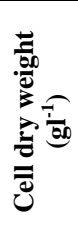 } & \multicolumn{4}{|c|}{ PHAs } & \multirow[b]{2}{*}{ 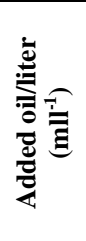 } & \multirow[b]{2}{*}{ 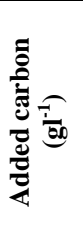 } & \multirow[b]{2}{*}{ 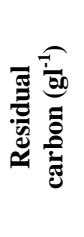 } & \multirow[b]{2}{*}{ 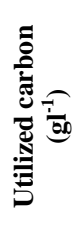 } & \multirow[b]{2}{*}{ 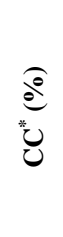 } \\
\hline & & & 泀 & 离 & 흘 & 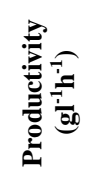 & & & & & \\
\hline \multirow{12}{*}{0.058} & 0 & 0.20 & - & - & - & - & 5.00 & 4.08 & 4.08 & 0.00 & - \\
\hline & 3 & 0.21 & - & - & - & - & 0.00 & 0.00 & 3.00 & 1.08 & - \\
\hline & 6 & 0.24 & - & - & - & - & 0.00 & 0.00 & 2.35 & 1.73 & - \\
\hline & 12 & 0.27 & - & - & - & - & 5.00 & 4.08 & 5.83 & 2.33 & - \\
\hline & 24 & 0.46 & - & - & - & - & 0.00 & 0.00 & 4.38 & 3.83 & - \\
\hline & 30 & 0.74 & - & - & - & - & 0.00 & 0.00 & 3.78 & 4.38 & - \\
\hline & 36 & 0.93 & 0.13 & 14.19 & 1.62 & 0.004 & 0.00 & 0.00 & 2.78 & 5.38 & 2.45 \\
\hline & 48 & 1.40 & 0.26 & 18.57 & 3.19 & 0.005 & 0.00 & 0.00 & 2.73 & 5.43 & 4.79 \\
\hline & 54 & 1.60 & 0.32 & 20.00 & 3.92 & 0.006 & 0.00 & 0.00 & 2.60 & 5.56 & 5.76 \\
\hline & 60 & 1.70 & 0.35 & 20.58 & 4.29 & 0.006 & 0.00 & 0.00 & 2.45 & 5.71 & 6.13 \\
\hline & 72 & 1.30 & 0.27 & 20.76 & 3.31 & 0.004 & 0.00 & 0.00 & 2.00 & 6.16 & 4.38 \\
\hline & & $0.82^{\mathrm{b}}$ & $0.27^{\mathrm{a}}$ & $18.8^{\mathrm{b}}$ & $3.27^{\mathrm{a}}$ & $0.005^{\mathrm{ab}}$ & $0.909^{\mathrm{a}}$ & $0.75^{\mathrm{a}}$ & $3.27^{\mathrm{a}}$ & $3.78^{\mathrm{a}}$ & $4.70^{\mathrm{a}}$ \\
\hline \multirow{12}{*}{0.039} & 0 & 0.20 & - & - & - & - & 2.50 & 2.04 & 2.04 & 0.00 & - \\
\hline & 3 & 0.22 & - & - & - & - & 0.00 & 0.00 & 1.09 & 0.95 & - \\
\hline & 6 & 0.28 & - & - & - & - & 0.00 & 0.00 & 0.99 & 1.05 & - \\
\hline & 12 & 0.30 & - & - & - & - & 2.50 & 2.04 & 2.47 & 0.56 & - \\
\hline & 24 & 0.58 & - & - & - & - & 2.50 & 2.04 & 1.56 & 2.95 & - \\
\hline & 30 & 0.64 & - & - & - & - & 0.00 & 0.00 & 0.95 & 3.56 & - \\
\hline & 36 & 0.90 & 0.10 & 11.11 & 1.23 & 0.004 & 2.50 & 2.04 & 2.51 & 4.04 & 2.48 \\
\hline & 48 & 0.94 & 0.15 & 15.95 & 1.84 & 0.003 & 0.00 & 0.00 & 2.00 & 4.55 & 3.30 \\
\hline & 54 & 0.99 & 0.17 & 18.08 & 2.08 & 0.003 & 0.00 & 0.00 & 1.90 & 4.65 & 3.66 \\
\hline & 60 & 1.03 & 0.20 & 19.41 & 2.50 & 0.003 & 0.00 & 0.00 & 1.71 & 4.84 & 4.13 \\
\hline & 72 & 1.06 & 0.24 & 22.64 & 2.94 & 0.003 & 0.00 & 0.00 & 1.12 & 5.43 & 4.42 \\
\hline & & $3.35^{\mathrm{a}}$ & $0.17^{\mathrm{c}}$ & $17.4^{\mathrm{c}}$ & $2.12^{\mathrm{c}}$ & $0.003^{\mathrm{c}}$ & $0.909^{\mathrm{a}}$ & $0.73^{\mathrm{c}}$ & $1.67^{\mathrm{c}}$ & $2.96^{\mathrm{c}}$ & $4.00^{\mathrm{b}}$ \\
\hline \multirow{11}{*}{0.023} & 0 & 0.20 & - & - & - & - & 3.33 & 2.72 & 2.72 & 0.00 & - \\
\hline & 3 & 0.24 & - & - & - & - & 0.00 & 0.00 & 2.00 & 0.72 & - \\
\hline & 6 & 0.38 & - & - & - & - & 0.00 & 0.00 & 1.55 & 1.17 & - \\
\hline & 12 & 0.46 & - & - & - & - & 0.00 & 0.00 & 0.88 & 1.84 & - \\
\hline & 24 & 0.56 & - & - & - & - & 3.33 & 2.72 & 2.35 & 3.09 & - \\
\hline & 30 & 0.70 & - & - & - & - & 0.00 & 0.00 & 1.69 & 3.75 & - \\
\hline & 36 & 0.82 & 0.13 & 15.82 & 1.59 & 0.004 & 0.00 & 0.00 & 0.66 & 4.78 & 2.72 \\
\hline & 48 & 0.99 & 0.22 & 22.22 & 2.70 & 0.005 & 3.33 & 2.72 & 2.45 & 5.71 & 3.85 \\
\hline & 54 & 1.15 & 0.27 & 23.47 & 3.31 & 0.005 & 0.00 & 0.00 & 1.52 & 6.64 & 4.10 \\
\hline & 60 & 1.19 & 0.30 & 25.21 & 3.68 & 0.005 & 0.00 & 0.00 & 1.47 & 6.69 & 4.48 \\
\hline & 72 & 1.23 & 0.33 & 26.82 & 4.10 & 0.005 & 0.00 & 0.00 & 1.34 & 6.82 & 4.84 \\
\hline Mean & & $0.72^{\mathrm{c}}$ & $0.25^{\mathrm{b}}$ & $22.7^{\mathrm{a}}$ & $3.07^{\mathrm{b}}$ & $0.005^{\mathrm{ab}}$ & $0.900^{\mathrm{b}}$ & $0.74^{\mathrm{b}}$ & $1.69^{\mathrm{b}}$ & $3.75^{\mathrm{b}}$ & $3.60^{c}$ \\
\hline
\end{tabular}

$* \mathrm{CC}(\%)=$ Conversion coefficient: Polymer concentration $\left(\mathrm{gl}^{-1}\right) /$ utilized carbon $\left(\mathrm{gl}^{-1}\right) \times 100$ (Ramadan et al., 1985)

Yield $(\%)=$ PHAs $\left(\mathrm{gl}^{-1}\right) /$ initial carbon $\left(\mathrm{gl}^{-1}\right) \times 100$ (Ramadan et al., 1985)

Productivity $\left(\mathrm{gl}^{-1} \mathrm{~h}^{-1}\right)=$ Polymer concentration $\left(\mathrm{gl}^{-1}\right) /$ fermentation time (h) $($ Lee, 1996)

Content $(\%)=$ Polymer concentration $\left(\mathrm{gl}^{-1}\right) /$ cell dry weight $\left(\mathrm{gl}^{-1}\right) \times 100$

Values in the same column followed by the same letter do not significantly differ from each other, according to Duncan's at $5 \%$ level. 
TABLE 2. Growth of Ps. fluorescens $\mathbf{S 4 8}$ and PHAs production on productive medium using bioreactor as fed-batch culture with continuous WFO type 2 feeding at the rates of $0.83,0.55$ and $0.42 \mathrm{mll}^{-1} \mathrm{~h}^{-1}$.

\begin{tabular}{|c|c|c|c|c|c|c|c|c|c|c|c|}
\hline \multirow[b]{2}{*}{ 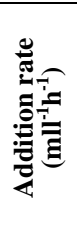 } & \multirow[b]{2}{*}{ 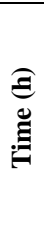 } & \multirow[b]{2}{*}{ 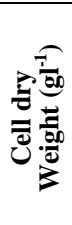 } & \multicolumn{4}{|c|}{ PHAs } & \multirow[b]{2}{*}{ 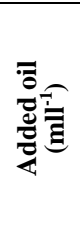 } & \multirow[b]{2}{*}{ مَ } & \multirow[b]{2}{*}{ 胥 } & \multirow[b]{2}{*}{$\underbrace{\widehat{2}}_{0}$} & \multirow[b]{2}{*}{$\underbrace{20}_{0}$} \\
\hline & & & & 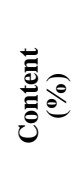 & $\frac{2}{8}$ & 国 & & & & & \\
\hline \multirow{10}{*}{0.83} & 0 & 0.26 & - & - & - & - & 0.00 & 0.00 & 0.00 & 0.00 & - \\
\hline & 3 & 0.28 & - & - & - & - & 1.25 & 0.20 & 1.80 & 22.50 & - \\
\hline & 6 & 0.61 & - & - & - & - & 5.00 & 1.74 & 2.26 & 28.25 & - \\
\hline & 12 & 0.74 & - & - & - & - & 10.00 & 4.83 & 3.17 & 39.63 & - \\
\hline & 18 & 0.80 & 0.10 & 12.50 & 1.25 & 0.005 & 0.00 & 4.2 & 3.8 & 47.50 & 2.63 \\
\hline & 24 & 0.84 & 0.20 & 23.80 & 2.50 & 0.008 & 0.00 & 3.58 & 4.42 & 55.25 & 4.52 \\
\hline & 30 & 1.10 & 0.28 & 25.45 & 3.50 & 0.007 & 0.00 & 2.85 & 5.15 & 63.38 & 5.44 \\
\hline & 48 & 1.16 & 0.46 & 39.65 & 5.75 & 0.010 & 0.00 & 1.94 & 6.06 & 75.75 & 7.59 \\
\hline & 72 & 1.17 & 0.48 & 41.20 & 6.00 & 0.006 & 0.00 & 1.24 & 6.76 & 84.50 & 7.11 \\
\hline & 96 & 1.09 & 0.36 & 33.11 & 4.51 & 0.004 & 0.00 & 1.19 & 6.81 & 85.13 & 5.31 \\
\hline Mean & & $0.81^{\mathrm{c}}$ & $0.36^{\mathrm{c}}$ & $32.66^{\mathrm{b}}$ & $4.45^{\mathrm{c}}$ & $0.007^{\mathrm{b}}$ & $1.81^{\mathrm{c}}$ & $1.95^{\mathrm{c}}$ & $4.05^{\mathrm{a}}$ & $50.49^{\mathrm{a}}$ & $5.99^{\mathrm{c}}$ \\
\hline \multirow{11}{*}{0.55} & 0 & 0.21 & - & - & - & - & 0.00 & 0.00 & 0.00 & 0.00 & - \\
\hline & 3 & 0.27 & - & - & - & - & 1.67 & 1.00 & 0.14 & 1.75 & - \\
\hline & 6 & 0.64 & - & - & - & - & 3.33 & 1.66 & 1.00 & 12.50 & - \\
\hline & 12 & 0.76 & - & - & - & - & 6.67 & 2.25 & 3.09 & 38.63 & - \\
\hline & 18 & 0.87 & 0.21 & 24.13 & 2.63 & 0.012 & 10.00 & 3.37 & 4.63 & 57.88 & 10.15 \\
\hline & 24 & 1.01 & 0.34 & 33.66 & 4.25 & 0.014 & 0.00 & 3.13 & 4.87 & 60.88 & 6.98 \\
\hline & 30 & 1.09 & 0.40 & 36.69 & 5.00 & 0.013 & 0 & 3.00 & 5.00 & 62.50 & 8.00 \\
\hline & 48 & 1.15 & 0.47 & 40.86 & 5.88 & 0.010 & 0.00 & 2.89 & 5.12 & 64.00 & 9.18 \\
\hline & 72 & 1.71 & 0.49 & 41.88 & 6.13 & 0.007 & 0.00 & 2.40 & 5.60 & 70.00 & 8.75 \\
\hline & 96 & 1.00 & 0.35 & 34.31 & 4.38 & 0.004 & 0.00 & 1.77 & 6.23 & 77.88 & 5.62 \\
\hline & & $0.85^{b}$ & $0.37^{b}$ & $34.97^{\mathrm{a}}$ & $4.65^{b}$ & $0.009^{\mathrm{a}}$ & $2.41^{\mathrm{a}}$ & $2.07^{b}$ & $3.41^{b}$ & $42.61^{\mathrm{b}}$ & $8.13^{\mathrm{b}}$ \\
\hline \multirow{10}{*}{0.42} & 0 & 0.23 & - & - & - & - & 0.00 & 0.00 & 0.00 & 0.00 & - \\
\hline & 3 & 0.82 & - & - & - & - & 1.25 & 0.20 & 0.80 & 10.00 & - \\
\hline & 6 & 0.84 & - & - & - & - & 2.50 & 0.40 & 1.60 & 20.00 & - \\
\hline & 12 & 0.92 & - & - & - & - & 5.00 & 1.57 & 2.43 & 30.38 & - \\
\hline & 18 & 0.99 & 0.15 & 15.15 & 1.87 & 0.008 & 7.56 & 2.88 & 5.12 & 64.00 & 2.93 \\
\hline & 24 & 1.18 & 0.26 & 22.03 & 3.25 & 0.011 & 10.00 & 4.41 & 3.59 & 44.88 & 7.24 \\
\hline & 30 & 1.22 & 0.29 & 23.77 & 3.63 & 0.010 & 0.00 & 3.90 & 4.10 & 51.25 & 7.07 \\
\hline & 48 & 1.62 & 0.51 & 31.48 & 6.38 & 0.011 & 0.00 & 3.41 & 4.59 & 57.38 & 11.11 \\
\hline & 72 & 1.66 & 0.60 & 36.14 & 7.50 & 0.008 & 0.00 & 3.12 & 4.88 & 61.00 & 12.30 \\
\hline & 96 & 1.62 & 0.50 & 30.86 & 6.25 & 0.005 & 0.00 & 2.11 & 5.89 & 73.63 & 8.49 \\
\hline Mean & & $1.12^{\mathrm{a}}$ & $0.43^{\mathrm{a}}$ & $28.86^{\mathrm{c}}$ & $5.40^{\mathrm{a}}$ & $0.009^{\mathrm{a}}$ & $2.09^{\mathrm{b}}$ & $2.12^{\mathrm{a}}$ & $3.10^{\mathrm{c}}$ & $38.72^{\mathrm{c}}$ & $9.24^{\mathrm{a}}$ \\
\hline
\end{tabular}

Initial carbon concentration $=8 \mathrm{gl}^{-1}$

*CC $(\%)=$ Conversion coefficient: Polymer concentration $\left(\mathrm{gl}^{-1}\right) /$ utilized carbon $\left(\mathrm{gl}^{-1}\right) \mathrm{X} 100$ (Ramadan et al., 1985)

$* *$ CUE $(\%)=$ Carbon utilization efficiency: Utilized carbon $\left(\mathrm{gl}^{-1}\right) /$ initial carbon $\left(\mathrm{gl}^{-1}\right) \mathrm{X} 100($ Ramadan et al., 1985).

Yield $=$ PHAs $\left(\mathrm{gl}^{-1}\right) /$ initial carbon $\left(\mathrm{gl}^{-1}\right) \times 100$ (Ramadan et al., 1985).

Productivity $\left(\mathrm{gl}^{-1} \mathrm{~h}^{-1}\right)=$ Polymer concentration $\left(\mathrm{gl}^{-1}\right) /$ fermentation time $(\mathrm{h})$ (Lee, 1996).

Content $(\%)=$ Polymer concentration $\left(\mathrm{gl}^{-1}\right) /$ cell dry weight $\left(\mathrm{gl}^{-1}\right) \times 100$.

Values in the same column followed by the same letter do not significantly differ from each other, according to Duncan's at $5 \%$ level.

Egypt. J. Microbiol. 47 (2012) 
PRODUCTION OF PHAS FROM WASTE FRYING OIL ...

TABLE 3. Growth of Ps. fluorescens S48 and PHAs production in productive medium using bioreactor as high-cell-density fed-batch culture with $0.36,0.64$ and $0.74 \mathrm{gl}^{-1}$ cell density and continuous WFO type 2 feeding at $0.55 \mathrm{mll}^{-1} \mathrm{~h}^{-1}$.

\begin{tabular}{|c|c|c|c|c|c|c|c|c|c|c|}
\hline \multirow[b]{2}{*}{ 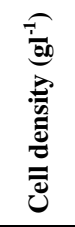 } & \multirow[b]{2}{*}{$\begin{array}{l}\underset{\Xi}{\Xi} \\
\stackrel{\Xi}{\Xi}\end{array}$} & \multirow[b]{2}{*}{ 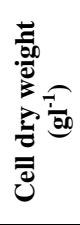 } & \multicolumn{4}{|c|}{ PHAs } & \multirow[b]{2}{*}{ 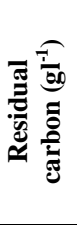 } & \multirow[b]{2}{*}{ 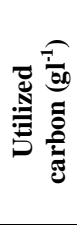 } & \multirow[b]{2}{*}{ 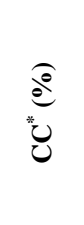 } & \multirow[b]{2}{*}{ 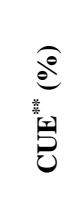 } \\
\hline & & & 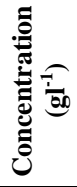 & 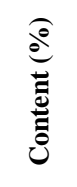 & 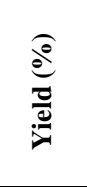 & 国 & & & & \\
\hline \multirow{9}{*}{0.36} & 0 & 0.36 & - & - & - & - & 0.00 & - & - & - \\
\hline & 6 & 0.46 & - & - & - & - & 3.12 & - & - & - \\
\hline & 12 & 0.50 & - & - & - & - & 5.88 & - & - & - \\
\hline & 24 & 0.97 & 0.21 & 21.64 & 2.63 & 0.009 & 5.26 & 2.74 & 7.66 & 34.25 \\
\hline & 30 & 1.10 & 0.29 & 26.36 & 3.63 & 0.010 & 3.90 & 4.10 & 7.07 & 51.25 \\
\hline & 36 & 1.30 & 0.40 & 30.76 & 5.00 & 0.011 & 3.28 & 4.72 & 8.47 & 59.00 \\
\hline & 48 & 1.75 & 0.66 & 37.71 & 8.25 & 0.014 & 2.80 & 5.10 & 12.94 & 63.75 \\
\hline & 54 & 1.64 & 0.69 & 42.07 & 8.63 & 0.013 & 1.84 & 6.16 & 11.20 & 77.00 \\
\hline & 60 & 1.60 & 0.74 & 46.25 & 9.25 & 0.012 & 1.17 & 6.83 & 10.83 & 85.38 \\
\hline \multirow[b]{2}{*}{ Mean } & 72 & 1.46 & 0.67 & 45.89 & 8.38 & 0.009 & 1.07 & 6.93 & 9.67 & 86.63 \\
\hline & & $1.12^{\mathrm{b}}$ & $0.52^{\mathrm{b}}$ & $35.8^{\mathrm{b}}$ & $6.54^{\mathrm{b}}$ & $0.11^{\mathrm{b}}$ & $2.83^{\mathrm{c}}$ & $5.23^{\mathrm{c}}$ & $9.69^{b}$ & $65.32^{\mathrm{a}}$ \\
\hline \multirow{11}{*}{0.64} & 0 & 0.64 & - & - & - & - & 0.00 & - & - & - \\
\hline & 6 & 0.90 & - & - & - & - & 3.86 & - & - & - \\
\hline & 12 & 1.10 & - & - & - & - & 6.86 & - & - & - \\
\hline & 24 & 1.38 & 0.47 & 34.05 & 5.88 & 0.020 & 5.26 & 2.74 & 17.15 & 34.25 \\
\hline & 30 & 1.40 & 0.50 & 35.71 & 6.25 & 0.017 & 4.86 & 3.40 & 14.71 & 42.50 \\
\hline & 36 & 1.68 & 0.70 & 41.67 & 8.75 & 0.02 & 2.77 & 5.23 & 13.38 & 65.38 \\
\hline & 48 & 3.46 & 1.72 & 49.71 & 21.50 & 0.036 & 2.07 & 5.93 & 29.00 & 74.13 \\
\hline & 54 & 3.92 & 1.66 & 42.34 & 20.75 & 0.031 & 1.95 & 6.05 & 27.44 & 75.63 \\
\hline & 60 & 3.10 & 1.15 & 37.09 & 14.38 & 0.019 & 1.44 & 6.56 & 17.53 & 82.00 \\
\hline & 72 & 2.94 & 1.10 & 37.41 & 13.75 & 0.015 & 1.05 & 6.95 & 15.83 & 86.88 \\
\hline & & $2.05^{\mathrm{a}}$ & $1.05^{\mathrm{a}}$ & $39.7^{\mathrm{a}}$ & $13.04^{\mathrm{a}}$ & $0.23^{\mathrm{a}}$ & $3.01^{\mathrm{a}}$ & $5.27^{\mathrm{b}}$ & $19.29^{\mathrm{a}}$ & $65.82^{\mathrm{b}}$ \\
\hline \multirow{11}{*}{0.74} & 0 & 0.74 & - & - & - & - & 0.00 & - & - & - \\
\hline & 6 & 0.90 & - & - & - & - & 4.42 & - & - & - \\
\hline & 12 & 0.28 & - & - & - & - & 7.58 & - & - & - \\
\hline & 24 & 0.19 & 0.015 & 7.89 & 1.87 & 0.0006 & 5.46 & 2.54 & 0.59 & 31.75 \\
\hline & 30 & 0.12 & 0.023 & 19.17 & 2.88 & 0.0007 & 3.20 & 4.80 & 0.48 & 60.00 \\
\hline & 36 & 0.102 & 0.025 & 24.51 & 3.12 & 0.0006 & 2.91 & 5.09 & 0.49 & 63.63 \\
\hline & 48 & 0.138 & 0.027 & 19.56 & 3.37 & 0.0005 & 1.60 & 6.40 & 0.42 & 80.00 \\
\hline & 54 & 0.140 & 0.031 & 22.14 & 3.87 & 0.0005 & 1.41 & 6.55 & 0.47 & 81.88 \\
\hline & 60 & 0.154 & 0.039 & 25.32 & 4.87 & 0.0006 & 1.25 & 6.75 & 0.58 & 84.38 \\
\hline & 72 & 0.204 & 0.065 & 31.86 & 8.12 & 0.0009 & 1.12 & 6.88 & 0.94 & 86.00 \\
\hline & & $0.30^{\mathrm{c}}$ & $0.32^{c}$ & $21.5^{\mathrm{c}}$ & $4.01^{\mathrm{c}}$ & $0.001^{\mathrm{c}}$ & $2.90^{\mathrm{b}}$ & $5.57^{\mathrm{a}}$ & $0.57^{\mathrm{c}}$ & $69.66^{\mathrm{a}}$ \\
\hline
\end{tabular}

Initial carbon concentration in oil $=8 \mathrm{gl}^{-1}$.

*CC $(\%)=$ Conversion coefficient: Polymer concentration $\left(\mathrm{gl}^{-1}\right) /$ utilized carbon $\left(\mathrm{gl}^{-1}\right) \mathrm{X}$ 100 (Ramadan et al., 1985).

$* *$ CUE $(\%)=$ Carbon utilization efficiency: Utilized carbon $\left(\mathrm{gl}^{-1}\right) /$ initial carbon $\left(\mathrm{gl}^{-1}\right) \mathrm{X}$ 100 (Ramadan et al., 1985).

Yield $=$ PHAs $\left(\mathrm{gl}^{-1}\right) /$ initial carbon $\left(\mathrm{gl}^{-1}\right) \times 100($ Ramadan et al., 1985).

Productivity $\left(\mathrm{gl}^{-1} \mathrm{~h}^{-1}\right)=$ Polymer concentration $\left(\mathrm{gl}^{-1}\right) /$ fermentation time (h) (Lee, 1996).

Content $(\%)=$ Polymer concentration $\left(\mathrm{gl}^{-1}\right) /$ cell dry weight $\left(\mathrm{gl}^{-1}\right) \times 100$.

Values in the same column followed by the same letter do not significantly differ from each other, according to Duncan's at $5 \%$ level. 
TABLE 4. Comparative data on PHAs production by Ps. fluorescens using different oils, feeding strategies and fermentation techniques.

\begin{tabular}{|c|c|c|c|}
\hline $\begin{array}{l}\text { Fermentation } \\
\text { technique }\end{array}$ & Media used & $\begin{array}{l}\text { Incubation } \\
\text { period } \\
\text { (h) }\end{array}$ & $\begin{array}{c}\text { Content } \\
(\%)\end{array}$ \\
\hline \multirow{3}{*}{$\begin{array}{l}\text { One-stage } \\
\text { bioreactor }\end{array}$} & $\begin{array}{l}\text { Productive medium containing corn oil }(2 \%) \\
\text { extracted from meal }\end{array}$ & 60 & $52.00^{\mathrm{b}}$ \\
\hline & $\begin{array}{l}\text { Productive medium containing soybean }(1 \%) \\
\text { extracted from meal }\end{array}$ & 60 & $76.80^{\mathrm{a}}$ \\
\hline & $\begin{array}{l}\text { Productive medium containing WFO type } 2 \\
(1 \%)\end{array}$ & 60 & $30.00^{\mathrm{c}}$ \\
\hline \multirow{3}{*}{$\begin{array}{l}\text { Two- } \\
\text { stage bioreactor }\end{array}$} & $\begin{array}{l}\text { Productive medium containing corn oil }(2 \%) \\
\text { extracted from meal }\end{array}$ & 48 & $68.70^{\mathrm{b}}$ \\
\hline & $\begin{array}{l}\text { Productive medium containing soy bean }(1 \%) \\
\text { extracted from meal }\end{array}$ & 48 & $78.20^{\mathrm{a}}$ \\
\hline & Productive medium containing WFO type $2(1 \%)$ & 60 & $47.37^{\mathrm{c}}$ \\
\hline \multirow{3}{*}{$\begin{array}{l}\text { Fed-batch } \\
\text { bioreactor, fed } \\
\text { with WFO type } 2\end{array}$} & Pulsed at specific addition rate of $0.023 \mathrm{mll}^{-1} \mathrm{~h}^{-1}$ & 72 & $26.82^{\mathrm{c}}$ \\
\hline & Continuous rate at $0.55 \mathrm{mll}^{-1} \mathrm{~h}^{-1}$ & 72 & $41.88^{\mathrm{b}}$ \\
\hline & $\begin{array}{l}\text { High cell density }\left(0.64 \mathrm{gl}^{-1}\right) \text { at continuous rate of } \\
0.55 \mathrm{mll}^{-1} \mathrm{~h}^{-1}\end{array}$ & 48 & $49.71^{\mathrm{a}}$ \\
\hline
\end{tabular}

Values in the same column followed by the same letter do not significantly differ from each other, according to Duncan's at $5 \%$ level.

\section{References}

Akiyama, M., Tsuge, T. and Doi, Y. (2003) Environmental life cycle comparison of polyhydroxyalkanoates produced from renewable carbon resources by bacterial fermentation Polym. Degrad. Stabil. 80, 183-194.

Alias, Z. and Tan, I.K.P. (2005) Isolation of palm oil-utilising, polyhydroxyalkanoate (PHA)-producing bacteria by an enrichment technique. Bioresour Technol. 96, 1229-1234.

Fern'andez, D., Rodr'ıguez, E., Bassas, M., Vĩnas, M., Solanas, A.M., Llorens, J., Marqu'es, A.M. and Manresa, A. (2005) Agro-industrial oily wastes as substrates for PHA production by the new strain Pseudomonas aeruginosa NCIB 40045:Effect of culture conditions. Biochemical Engineering Journal, 26 , 159-167.

Gamal, Rawia F., Abd El- Hady, Hemmat M. ,Hassan, Enas A., El-Tayeb, T. S. and Aboutaleb, Khadiga, A. (2011) Production of polyhydroxyalkanoate (PHAs) and copolymer [P(HB-co-HV)] by soil bacterial isolates in batch and two-stage batch cultures. Egypt. J. Microbiol. 46, 109-123.

Grothe, E. and Chisti, Y. (2000) Poly ( $\beta$-hydroxybutyric acid) thermoplastic production by Alcaligenes latus: behavior of fed-batch cultures. Bioproc. Eng. 22, 441-449.

Grothe, E., Moo-Young, M. and Chisti, Y. (1999) Fermentation optimization for the production of poly ( $\beta$-hydroxybutyric acid) microbial thermoplastic. Enzyme Microb. Technol. 25, 132-141.

Egypt. J. Microbiol. 47 (2012) 
Hahn, S.K., Chang, B., Kim, S. and Chang, H.N. (1994) Optimization of microbial poly (3-hydroxybutyrate) recovery using dispersions of sodium hypochlorite solution and chloroform. Biotechnol. Bioeng. 44, $256-261$.

IBM $^{\circledR}$ SPSS $^{\circledR}$ Statistics (2011) Version 19.0, SPSS Inc., Chicago, Illinois.

Jacobs, M.B. and Gerstein, M.J. (1960) "Handbook of Microbiology". Nostrand, D.V. (Ed.) Co., Inc., New York, pp.139 - 202.

Jacquel, N., Lo, Ch.W., Wei, Y.H., Wu, H.Sh. and Wang, Sh.S. (2008) Isolation and purification of bacterial poly ( $\beta$-hydroxyalkanoates). A review. Biochem. Engin. J. 39, $15-27$.

Lee, K.M. and Gilmore, D.F. (2006) Modeling and optimization of biopolymer (polyhydroxyalkanoates) production from ice cream residue by novel statistical experimental design. Appl. Biochem. Biotechnol. 133, 113 - 148.

Lee, S.Y. (1996) Plastic bacteria. Progress and prospects for polyhydroxyalkanoate production in bacteria. Trends Biotechnol. 14, $431-438$.

Lee, S.Y. and Choi, J. (1998) Polyhydroxyalkanoates biodegradable polymer. In: "Manual of Industrial Microbiology and Biotechnology" ( $2^{\text {nd }}$ ed.), Demain, A.L. and Davies, J.E. (Ed.). pp. 616 - 627. ASM Press, Washington, D.C.

Lopez-Cuellar, M.R., Alba-Flores, J., Gracida Rodrîguez, J.N. and Pérez-Guevara, F. (2011) Production of polyhydroxyalkanoates (PHAs) with canola oil as carbon source. International Journal of Biological Macromolecules, 48, 74-80.

Patwardhan, P.R. and Srivastava, A.K. (2004) Model-based fed-batch cultivation of $R$. eutropha for enhanced biopolymer production. Biochem. Eng. J. 20, $21-28$.

Ramadan, E.M., El-Sawy, M., Gamal, Rawia F. and Abdelhady, Hemmat M. (1985) Growth parameters of yeast grown on agricultural residues using shake flasks as a batch culture. Annals Agric. Sci., Fac. Agri., Ain Shams Univ., Cairo, Egypt. 30, 25 - 45.

Shahhosseini, Sh. (2004) Simulation and optimization of PHB production in fed-batch culture of Ralstonia eutropha. Process Biochem. 39, 963 - 969.

Steinbüchel, A. (1995) Use of biosynthetic, biodegradable thermoplastics and elastomers from renewable resources, The pros and cons, JMS Pure Appl. Chem. 32, 653 - 660.

Sun, Z., Ramsay, J.A., Guay, M. and Ramsay, B. (2007) Increasing the yield of MCLPHA from nonanoic acid by co-feeding glucose during the PHA accumulation stage in two-stage fed-batch fermentations of Pseudomonas putida KT2440. J. Biotechnol. 132, $280-282$. 
Valappil, S.P., Misra, S.K., Boccaccini, A.R., Keshavarz, T., Bucke, C. and Roy, I. (2007) Large-scale production and efficient recovery of PHB with desirable material properties, from the newly characterized Bacillus cereus SPV. J. Biotechnol. 132, 251-258.

Verlinden, R.A.J., Hill, D.J., Kenward, M.A., Williams,C.D., Zofia Piotrowska-Seget and Radecka, I.K.(2011) Production of polyhydroxyalkanoates from waste frying oil by Cupriavidus necator. AMB Express, 1:11 http: //www. amb-express. com/ content/ 1/1/11.

Walinga, I., Kithome, M., Novozamsky, I., Houba, V.J.G. and Van der Lee, J.J.(1992) Spectrophotometric determination of organic carbon in soil. Commun Soil Sci. Plant Anal. 23, 1935 - 1944.

Yan, Q., Sun, Y., Ruan, L.F., Chen, J. and Yu, P.H.F. (2005) Biosynthesis of shortchain-length-polyhydroxyalkanoates during the dual-nutrient-limited zone by Ralstonia eutropha. World J. Microbiol. Biotechnol. 21, 17 - 21.

(Received 19/6/2011; accepted 5/10/2011) 


\section{إنتاج البولى هيدروكسى الكونيت (PHAs) من مخلفات زيت

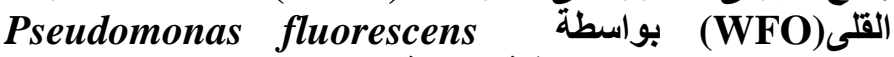 باستخدام المخمر بطرق تغذية مختلفة}

راوية فتحى جمال، همت محمد عبد الهادى، ايناس عبد التواب حسن ، طابه عبد

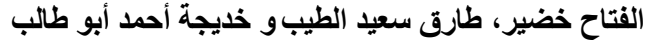

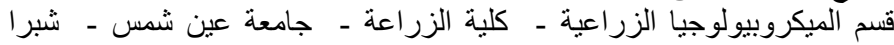

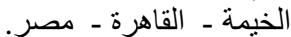

تعتبر مركبات البولى هيدروكسى الكونيت (PHAs) وسيلة لمواد بلاستيكية

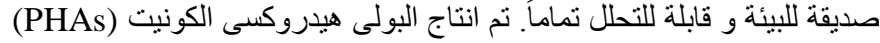

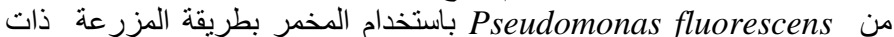

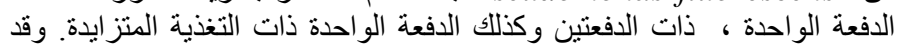

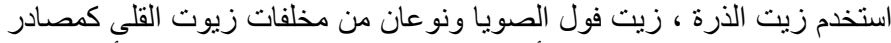

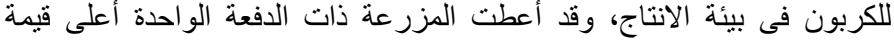

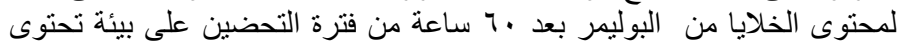

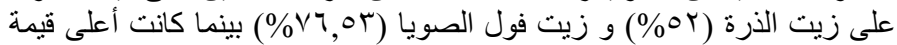

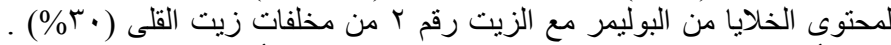

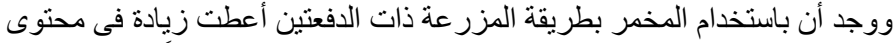

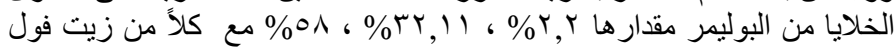

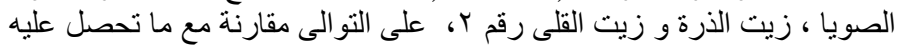

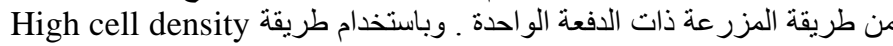

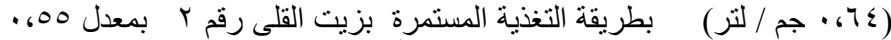

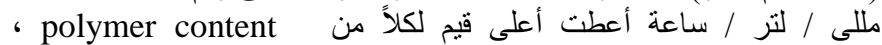
بield و conversion coefficient

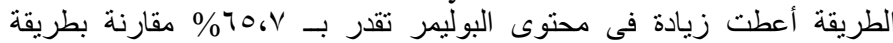

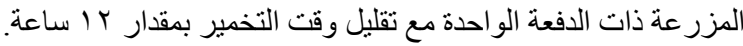

